ASIAN YEARBOOK OF INTERNATIONAL LAW 


\title{
FOUNDATION FOR THE DEVELOPMENT OF INTERNATIONAL LAW IN ASIA (DILA)
}

\author{
Governing Board
}

(As at 1 January 2003)

Florentino P. Feliciano (Phil., Manila)

Jamshed A. Hamid (Pak., Islamabad)

Rahmatullah Khan (Ind., New Delhi)

Ko Swan Sik (Indon., The Hague)

Tommy T.B. Koh (Sing., Singapore)

Kriangsak Kittichaisaree (Chairman, Thai, Bangkok)

Kozai Shigeru (Jap., Osaka)

Li Zhaojie (Chin., Beijing)

R.St.J. Macdonald (Can., Toronto)
Nakatani Kazuhiro (Treasurer, Jap., Tokyo)

Park Choon Ho (Kor., Seoul)

M.C.W. Pinto (Sr.Lan., The Hague)

S.J. Seifi (Vice-Chairman, Ir., Tehran)

Surya P. Subedi (Nep., London)

Sompong Sucharitkul (Thai, San Francisco)

J.J.G. Syatauw (Neth., Oegstgeest)

K. Tan Yew Lee (Sing., Singapore)

\section{Support received from:}

- Netherlands Ministry of Development Cooperation (1991)

- Swedish International Development Authority (1994)

-The Japan Foundation (1996)

\author{
Patrons: \\ - The Paeksang Foundation, Seoul \\ - Tokibo Co., Ltd., Tokyo \\ Patronage and donations: \\ As of 1997, upon donation to the Foundation of US\$10,000 or more, \\ the donor will be designated Patron of the Foundation
}

Mailing addresses:

For DILA matters:

Prof. Kriangsak Kittichaisaree

35/304 Noble House Phayathai Bldg., 27th

Floor (27C),

Phayathai Road, Ratchataevee, Bangkok

10400, Thailand

e-mail: kriangsakkitt@hotmail.com
For Yearbook matters:

Prof. S.P. Subedi,

6 Manorside, Barnet, EN5 2LD, UK

e-mail: s.p.subedi@mdx.ac.uk 


\section{Asian Yearbook of \\ International Law}

published under the auspices of the

Foundation for the Development

of International Law in Asia (DILA)

General Editors

(As at 1 January 2003)

B.S. Chimni - Ko Swan Sik - Miyoshi Masahiro

M.C.W. Pinto - S.P. Subedi

\section{VOLUME 8 \\ 1998/1999}

MARTINUS NIJHOFF PUBLISHERS

LEIDEN / BOSTON 
Published by:

Brill Academic Publishers

P.O. Box 9000, 2300 PA Leiden, The Netherlands

cs@brill.nl

http://www.brill.nl

A C.I.P. Catalogue record for this book is available from the Library of Congress.

(c) 2003 Koninklijke Brill NV, Leiden, The Netherlands

Layout and camera-ready copy: Anne-Marie Krens, Oegstgeest, The Netherlands

Printed on acid-free paper.

Brill Academic Publishers incorporates the imprint Martinus Nijhoff Publishers.

All rights reserved. No part of this publication may be reproduced, stored in a retrieval system, or transmitted in any form or by any means, electronic, mechanical, photocopying,

microfilming, recording or otherwise, without written permission from the Publisher.

Authorization to photocopy items for internal or personal use is granted by Brill Academic Publishers provided that the appropriate fees are paid directly to The Copyright Clearance Center, 222 Rosewood Drive, Suite 910, Danvers MA 01923, USA. Fees are subject to change.

Printed and bound in The Netherlands 


\section{ASIAN YEARBOOK OF INTERNATIONAL LAW}

\section{Advisory Council}

(As at 1 January 2003)

Bharat Desai, New Delhi

Florentino P. Feliciano, Manila

Mochtar Kusuma-Atmadja, Jakarta

Roy S. Lee, New York

Nguyen Hong Thao, Hanoi

F.X. Njenga, Nairobi
Onuma Yasuaki, Tokyo

R. Pangalangan, Manila

Park Ki-Gab, Seoul

P. Chandrasekara Rao, New Delhi

Datuk Wira Lal C. Vohrah, Kuala Lumpur

\section{Editorial Board}

(As at 1 January 2003)

B.S. Chimni, New Delhi

Rahmatullah Khan, New Delhi

Kim Charn Kiu, Seoul

Ko Swan Sik, The Hague

Kriangsak Kittichaisaree, Bangkok

Li Zhaojie, Beijing

R.P.M. Lotilla, Manila

Miyoshi Masahiro, Aichi
Nakatani Kazuhiro, Tokyo

M.C.W. Pinto, The Hague

S.J. Seifi, Tehran

S.P. Subedi, London

Sompong Sucharitkul, San Francisco

Takane Sugihara, Kyoto

$K$. Tan Yew Lee, Singapore

K.I. Vibhute, Pune

\section{Associate Editor}

Karin Arts

The Hague

\section{National Correspondents}

Choe Kyong Soo, Seoul

Jamshed A. Hamid, Islamabad

S. Charika Marasinghe, Colombo

Kotera Akira, Tokyo

Lo Lai Mee, Kuala Lumpur
V.S. Mani, New Delhi

Matsui Yoshiro, Nagoya

Soh Tze Bian, Singapore

Wan Arfah Hamzah, Kuala Lumpur 
The DILA Foundation and the Yearbook are greatly saddened by the death of

$$
\text { Professor Wang Tieya }
$$

on 12 January 2003.

His advice and guidance were always available to the Foundation, and his life and work will continue to inspire all those who knew him. 


\section{TABLE OF CONTENTS}

Abbreviations

ix

\section{ARTICLES}

Zhao Yun, Liberalization of air transport services under the framework of the WTO: confronting the challenge of the twenty-first century

Alberta Fabbricotti, The ASEAN Free Trade Area (AFTA) and its compatibility with the GATT/WTO

Mizukami Chiyuki, The fisheries policy of Japan under the new Law of the Sea

Eric Yong-Joong Lee, Establishment of a de jure peace on the Korean peninsula: inter-Korean peace treaty-making under international law

Kong Qingjiang, Bilateral investment treaties: the Chinese approach and practice

Nguyen Hong Thao, Vietnam and joint development in the Gulf of Thailand

\section{LEGAL MATERIALS}

State practice of Asian countries in the field of international law

- Japan

- The Philippines

Participation in multilateral treaties

ASIA AND INTERNATIONAL ORGANIZATIONS

Asian-African Legal Consultative Committee: Bi-annual survey of activities 1998-1999 


\section{CHRONICLE}

Chronicle of events and incidents relating to Asia with relevance to international law: July 1997 - June 1999

\section{LITERATURE}

Book reviews

Bibliography

Index

General information

Announcements

Sata Prize 